\title{
The Effect of Basic Life Assistance Training (BHD) on Motivation and demeanour of Class XI Students in Rescuing Traffic Accidents in SMA Negeri 2 Tenggarong
}

\author{
Alfi Ari Fakrur Rizal ${ }^{1}$, Indah Nur Imamah $^{2}$, Milkhatun ${ }^{3}$ \\ ${ }^{1}$ Department of Nursing, Faculty of Health and Pharmacy, Universitas Muhammadiyah \\ Kalimantan Timur \\ ${ }^{2}$ Department of Nursing, Poltekkes Kemenkes Kalimantan Timur \\ ${ }^{3}$ Department of Nursing, Faculty of Health and Pharmacy, Universitas Muhammadiyah \\ Kalimantan Timur \\ Corresponding Author : aafr597@umkt.ac.id
}

\begin{abstract}
Traffic accidents are one of the public health problems that affect all sectors of life. The phenomenon of traffic accidents so far has not received much public attention as a cause of death. The increase in mortality rates that occur on the highway is very high and quite a concern and vigilance for the community. This usually happens one of them because the Indonesian people do not know how to help victims who are good and right when finding victims. As a result most of actions is wrong, so it can add to injury and death. This study aims to determine the effect of basic life support training (BHD) on the motivation and demeanour of class XI students in rescuing traffic accidents in SMA Negeri 2 Tenggarong. This study uses a quasy experimental method of pre and post design with a control group. Proportional stratified random sampling technique with a sample of 78 students and data collection using a questionnaire sheet. Data that was analyzed by paired t test in each group showed a p-value of $0,000<0.05$, meaning that there was a statistically change in motivation and attitude between before and after treatment in the form of BHD training for class XI students at SMAN 2 Tenggarong. The result is not much different from the independent $t$ test which showed $p$-value $0,000<0.05$, which means there is a statistically different demeanour between the difference before and after treatment in the form of BHD training in the control and intervention groups. The results showed that there was a statistically significant change in motivation and demeanour between before and after the BHD training was given to the motivation and demeanour of class XI students at SMAN 2 Tenggarong with a p-value of $0,000<0.05$.
\end{abstract}

Keywords : Student Motivation, Student demeanours, Basic Life Assistance Training 


\section{INTRODUCTION}

Traffic accidents are one of the public health problems that can affect all parts of life. Until now, traffic accidents have not received much public attention as a cause of death. According to the World Health Organization (WHO) traffic accidents in Indonesia are rated as the fifth largest killer in the world (Wahyu, Muhammad \& Irhamah, 2012). Data according to the World Health Organization (WHO) also states that every day at least 3,000 million people die from accidents (WHO, 2011).

Death occurs usually due to the inability to deal with sufferers in the emergency phase (Golden Period). This inability can be caused by the severity, inadequate equipment, lack of an integrated system, and knowledge, as well as lack of motivation in emergency response. The right help in handling emergency cases is Basic Life Support or Basic Life Support (BHD). Seeing these conditions we all must always increase efforts to prevent and reduce the occurrence of traffic accidents. One example is providing guidance, training to increase knowledge and motivation about safety and first aid for road accidents to students. The first hour is a very important time in first aid for accident victims, which can reduce up to $85 \%$ of mortality. The help in question is Basic Life Assistance (BHD) (Pamaya, 2014). Basic Life Support (BHD) is an effort made to restore and maintain the function of vital organs in victims of cardiac arrest and respiratory arrest (Hardisman, 2014).

The reality in the field is that basic life support (BHD) assistance is not easy to do, especially for ordinary people. One of the layers of society as competent helpers to be trained are high school students. In 2010, around 1.1 billion of the world's population were teenagers, which is a part of ordinary people (WHO, 2010). Indonesia's population in 2010 totaled 237.6 million people and $26.67 \%$ or 63.4 million of them were teenagers (Wong in Thoyyibah, 2014).

Adolescents who are classified as students at the high school level (SMA) should at least be able to perform cardiac pulmonary resuscitation, dressing and splint properly. Because basic life support (BHD) training for high school students is very important and beneficial to increase the number of people trained (bystander) in providing basic life assistance (BHD) either in their neighborhood or at school. The provision of this training can also broaden students' insights and knowledge so that they can motivate them to provide basic life support (BHD) in emergencies where unexpected emergencies are immediately possible (AHA, 2010).

According to Sitorus (2011) motivation can change at any time and develop according to one's level of awareness of the goals they want to achieve. The stronger motivation one has does not mean that the person is approaching the goal but it can also be vice versa, namely someone who is getting stronger away from the goal in the sense of increasing the initial goal and trying to pursue another goal. Knowing the absolute goals is very necessary in order to maintain and strengthen motivation. Some factors that influence students in dealing with accidents are knowledge, demeanour and readiness in the critical situation of adolescents is expected to be a bystander in their environment. According to Thoyyibah (2014) adolescents have developmental characteristics in body size, strength, psychological, reproductive ability, easily motivated to quickly learn so that information and knowledge gained can be better understood and applied, one of them is training which can later influence the training the attitude of students in dealing with victims of traffic accidents.

\section{RESEARCH METHODS}

This study uses a quasy experimental design with Non equivalent control group design that aims to see the effect of basic life support training on the attitude of students in class XI in providing assistance to traffic accidents at SMAN 2 Tenggarong. This design has two groups, namely the intervention group and the control group, the control group cannot function fully to control external variables that affect the implementation of the experiment. Individuals between the two groups are different, but each group is expected to have equality, therefore a pretest is conducted to determine the initial conditions, whether there is a difference in equality between the intervention group and the control group. Before the intervention group was treated, an initial measurement (pretest) was made in the intervention group and the control group to determine initial ability.

Furthermore, the intervention group was treated while the control group was not treated. The treatment carried out in this study was basic life support training (BHD). Then the final measurement (post test) was carried out in the intervention and control groups. 


\section{Result}

\section{RESULTS AND DISCUSSION}

A. Characteristics of Respondents Distribution of respondents in the intervention and control groups as follows:

Table 1 Characteristics of class XI respondents in the intervention and control groups at SMAN 2

$$
\begin{aligned}
& \text { Tenggarong in } 2019 \\
& \text { Source: Primary Data }
\end{aligned}
$$

Based on table 1 shows that the number of respondents in the intervention group was 39 people and in the control group was 39 people with the number of men in the intervention group totaling 17 people (44\%) and 19 people (49\%) in the control group. In the female sex group, the majority of respondents in the intervention group numbered 22 people $(56 \%)$ and for the control group they totaled 20 people (51\%). The age of respondents with the highest number was 16 years $(56 \%)$, the lowest number was 18 and 19 years old (3\%). In general respondents in the two groups had never received information about basic life support. As many as 31 people $(79 \%)$ had never received information about basic living assistance and the rest sebanyak 8 orang (21\%) memperoleh informasi about basic life support from PMI in the intervention group. Similarly, the control group of 37 people (97\%) had never received information about basic living assistance and the remaining 2 people $(5 \%)$

\begin{tabular}{lcccc}
\hline \multirow{2}{*}{ Characteristics of Respondents } & \multicolumn{2}{c}{ Intervention Group } & \multicolumn{2}{c}{ Control Group } \\
\cline { 2 - 5 } & $\mathrm{n}(39)$ & $\%$ & $\mathrm{n}(39)$ & $\%$ \\
\hline 1. Age & 22 & $56 \%$ & 19 & $49 \%$ \\
16 years old & 15 & $38 \%$ & 18 & $46 \%$ \\
17 years old & 1 & $3 \%$ & 2 & $5 \%$ \\
18 years old & 1 & $3 \%$ & - & - \\
\hline years old & & & & \\
2. Gender & 17 & $44 \%$ & 19 & $49 \%$ \\
$\quad$ Male & 22 & $56 \%$ & 20 & $51 \%$ \\
$\quad$ Female & & & & \\
3. Ever get information about BHD & 8 & $21 \%$ & 2 & $5 \%$ \\
Yes & 31 & $79 \%$ & 37 & $95 \%$ \\
$\quad$ No & - & & & \\
\hline 4.Information Resource & 8 & $21 \%$ & - & - \\
$\quad$ Puskesmas & 31 & $79 \%$ & 37 & $95 \%$ \\
PMI & & & & \\
Nothing & & & & \\
\hline
\end{tabular}

received information about basic living assistance from the Puskesmas.

Tabel 2 Test of normality using Shapiro-Wilk

\begin{tabular}{lll}
\hline Category & Shapiro-Wilk & information \\
\hline Intervention Group & & \\
\hline Pre test & 0.476 & Normal \\
Post test & 0.555 & Normal \\
\hline Control Group & & \\
\hline Pre test & 0.916 & Normal \\
Post test & 0.659 & Normal \\
\hline
\end{tabular}

Source: Primary Data

Based on table 2 of the tests using Shapiro-Wilk the results obtained in the pre-test intervention group were 0.476 (normal), 0.555 post-test (normal), and in the control group the pre-test value was 0.916 (normal), and the post-test was 0.659 (normal). It can be concluded that the data is normally distributed, so the bivariate test used is the parametric test, which is paired $t$ test and independent $t$ test.

A. Univariate Analysis includes the difference in the average results of basic life support training to student demeanour before and after treatment between the intervention group and the control group 
Table 3 differences in the average results of the attitude of class XI students before and after the treatment was given between the intervention group and the control group

\begin{tabular}{lcccccc}
\hline \multirow{2}{*}{ Variable } & \multicolumn{5}{c}{ Data Result } \\
\cline { 2 - 7 } & $\mathrm{N}$ & Mean & Median & Min & Max & SD \\
\hline Intervention Group & & & & & & \\
\hline Before & 39 & 88.59 & 90 & 77 & 100 & 5.748 \\
After & & 95.62 & 95 & 87 & 103 & 3.816 \\
\hline Control Group & & & & & & \\
\hline Before & 39 & 83.21 & 83.5 & 70 & 96 & 6.217 \\
After & & 84.55 & 85.5 & 70 & 96 & 5.985 \\
\hline
\end{tabular}

Sumber : Data Primer

Based on table 3 the mean difference in the results of basic life support training before being treated in the intervention group obtained an average value of 88.59 , a median value of 90 with the lowest value being 78 and a highest value of 100 and a standard deviation value of 5,748. Then in the control group the average value of respondents was lower at 83.21, the median value was 83.5 with the lowest value of 70 and the highest value of 96 and the standard deviation value of 6.217.

While the mean difference in the results of basic life support training after being treated in the intervention group obtained an average value of 95.62, a median value of 95 with the lowest value being 87 and the highest value 103 and a standard deviation value of 3,816 . Then in the control group the average value of respondents was lower at 84.55 , the median value of 85.5 with the lowest value of 70 and the highest value of 96 and the standard deviation of 5.985 .

A. Bivariate analysis includes differences in the average motivation and attitude of students in class XI before and after treatment between the intervention group and the control group using a paired ttest and the difference in the difference in the motivation and attitude of students in class XI between the intervention group and the control group by using the independent t-test.

Table 4 Differences in the average demeanour of class XI adolescents before and after treatment in each group using the paired t-test

\begin{tabular}{lccccccc}
\hline \multirow{2}{*}{ Variable } & \multicolumn{7}{c}{ Data Result } \\
\cline { 2 - 8 } & $\mathrm{N}$ & Mean & SD & SE & $95 \% \mathrm{CI}$ & $\mathrm{T}$ & P-value \\
\hline Intervention Group & \multirow{2}{*}{39} & 88.59 & 5.748 & 0.920 & -8.224 & -11.872 & $0.000^{*}$ \\
$\quad$ Before & & 95.62 & 3.816 & 0.611 & -5.828 & & \\
After & & & & & & & \\
\hline Control Group & 39 & 83.21 & 6.217 & 1.009 & -1.726 & -7.078 & $0.000^{*}$ \\
Before & & 84.55 & 5.985 & 0.971 & -0.958 & & \\
After & & & & &
\end{tabular}

$* \mathrm{p}=$ nilai signifikan $\alpha \leq 0.05$

Resource : Primary Data

Based on table 4 the average difference in each group obtained results in the intervention group the average value of students' motivation and demeanour before training is Mean 88.59 SD 5.748, SE $0.920,95 \% \mathrm{CI}-8.224, \mathrm{~T}-11.872$ and $\mathrm{p}$-scores value $0.000<0.05$ Then the average motivation and attitude of students after being treated in the intervention group with Mean 95.62, SD 3.816, SE 0.611, 95\% CI -5.828, T-11.872 and p-value $0.000<0.05$.

While the difference in the average motivation and attitude of students in class XI in the control group obtained the average motivation and attitude of students before the basic life support training 
with Mean 83.21, SD 6.217, SE 1,009, 95\% CI -1,726, T-7,078, and grades p-value $0,000<0.05$. Then the average motivation and attitude of students after basic life support training in the control group with a mean of $84.55, \mathrm{SD} 5995, \mathrm{SE} 0.971,95 \%$ CI $-0.958, \mathrm{~T}-7078$ with a p-value of $0.000<0.05$.

So it can be concluded that there is a statistically significant difference between before and after treatment is given in the form of basic assistance training in the intervention group.

Table 5 Difference in the average difference in motivation and demeanour of class XI students between the intervention group and the control group using the independent $t$-test

\begin{tabular}{ccccccc}
\hline \multicolumn{7}{c}{ Difference in Post Test Data to Pre Test } \\
\hline Group & Mean & SD & Mean Different & $95 \%$ CI & t & $P$-value \\
\hline Intervention & 7.03 & 3.69 & -11.06 & $(-13.3)-(-8.7)$ & -9.64 & 0.000 \\
\hline Control & 1.34 & 1.16 & &
\end{tabular}

Resource : Primary Data

Based on table 5 above, the results obtained in the two groups (intervention and control) with the difference between posttest to pretest were the mean for the intervention group was 7.03, SD 3.69 mean different $-11.06,95 \%$ CI (-13.3) - (- 8.7) $t$ count -9.64 , and $p$-value 0,000 . While the mean for the control group is 1.34 , SD 1.16, mean different $-11.06,95 \% \mathrm{CI}(-13.3)-(-8.7) \mathrm{t}$ count -9.64 , and pvalue 0.000 .

So it can be concluded that there is a statistically significant difference between motivation and demeanour of class XI students in the intervention group with the control group before and after basic life support training (BHD) is given.

\section{A. Discussion}

Characteristics of Respondents

1) Gender

The results showed that the number of respondents in the treatment group was 39 people and in the control group was 39 people with the number of men in the treatment group totaling 17 people (44\%) and 19 people (49\%) in the control group. In the female sex group, the majority of respondents in the treatment group numbered 22 people $(56 \%)$ and for the control group there were 20 people $(51 \%)$.

In a study conducted by Erawati (2015) said that the sexes of men and women have the same knowledge about basic life support. Knowledge is information or information that is known or realized by someone. Knowledge Appears when someone uses his mind to recognize certain events that have never been seen or felt before.

So it can be said that knowledge is information that has been combined with understanding and the potential for action that will later be oriented to one's attitude in applying that knowledge. Demeanour will arise if there is knowledge and experience.

When viewed from the sexes of men and women the way of thinking in men and women is almost the same so that the knowledge obtained is also the same that distinguishes only the perspective of experience and individual abilities in learning. Based on the above research, researchers assume that gender does not affect a person's demeanour.

2) Age of Respondent

The results showed that the age of students who were respondents in the treatment group with the highest number was 16 years (56\%), the lowest number was age 18 and 19 years (3\%). Similarly, the treatment group in the control group with the highest number was age 16 years (49\%) and the lowest age was 18 years $(5 \%)$.

According to Panuju \& Umami (1999, in Jafar 2006) the age range of adolescents is in the age of 1221 years for women and 13-22 years for men. If divided into early and late adolescents, the early adolescents are at the age of 12 or 13 years to 17 or 18 years and late teens in the age range 17 or 18 years to age 21 or 22 years. Teenagers who are in development on body size, strength, psychological, reproductive ability, easy to be motivated and fast learners, are expected to be observers in their environment. These characteristics can be found in adolescents at the high school level.

Juliana et al (2010, in Hutapea, 2012), said that the younger the individual's age, the higher the ability to remember to remember the information received. Older individuals will experience a physiological decline in the body which will affect the ability to remember information. However, in terms of age- 
old individual thinking patterns are generally more mature in terms of attitude and decision making in an effort to solve complex and abstract problems.

Their capacity to think logically and abstractly develops so that they are able to think rationally, no longer accepting information as it is, but they will process the information and adapt it to their own thoughts. So that individuals with older age are able to integrate past and present experiences to be transformed into conclusions, predictions and plans in terms of acting in response to problems that are around them.

Based on the above research, researchers assume that age influences a person's attitude because in adolescence two thought patterns have been formed, namely hypotheses and abstracts that make adolescents able to make informed decisions when meeting a case in their environment.

\section{3) Information and Resources About Basic Living Assistance (BHD)}

From the results of the data obtained in general respondents in the two groups have never received information about basic life support (BHD). As many as 31 people (79\%) had never received information about basic living assistance and the remaining 8 people $(21 \%)$ received information about basic living assistance from PMI in the intervention group. Similarly, the control group of 37 people $(95 \%)$ had never received information about basic life support and the remaining 2 people $(5 \%)$ received information about basic living assistance from the Puskesmas.

According to Henry and Dewi (2010) Factors that influence demeanour include personal experience, the influence of others who are considered important, the influence of culture. mass media, educational institutions and religious institutions as well as emotional factors. The existence of new information and experiences received about a matter can provide a new cognitive basis for the formation of demeanour towards it.

According to Hardiani (2013) a person's level of knowledge increases if someone is often or has been exposed to information. The information can be in the form of listening, seeing or having direct experience of an activity experienced by someone. So

So it can be said that knowledge is information that has been combined with understanding and the potential for action that will later be oriented to one's attitude in applying that knowledge. Demeanour will arise if there is knowledge and experience.

Based on the results of this study the researcher can assume that the information and experiences that have been received by someone can influence one's attitude towards actions and decisions taken.

B. Univariat Analysis

1) Motivation and attitude of students before and after treatment given basic life support training between the intervention group and the control group

Based on the results of the average difference table (mean) results of basic life support training to the demeanour of students before being treated in the intervention group obtained an average value of 88.59 , a median value of 90 with the lowest value was 77 and a highest value of 100 and a standard deviation value of 5,748. Whereas in the control group the mean score of respondents was lower at 83.21, the median value of 83.5 with the lowest value of 70 and the highest value of 96 and the standard deviation value of 6.217 .

Difference in mean (mean) results of basic life support training after being treated in the intervention group obtained an average value of 95.62, a median value of 95 with the lowest value was 87 and the highest value 103 and a standard deviation value of 3,816 . Whereas in the control group the mean score of respondents was lower at 84.55 , the median value of 85.5 with the lowest value of 70 and the highest value of 96 and the standard deviation value of 5.985.

According to Wawan and Dewi (2010) there are 6 factors that influence motivation and demeanour, namely personal experience, the influence of others who are considered important, the influence of mass media culture, educational institutions and religious institutions and emotional factors. Demeanour are views or feelings accompanied by a tendency to act according to the object's attitude. The attitude is formed because of the knowledge and experience so that it takes experience or real action to students so students know directly the situation and conditions and students can behave in accordance with the conditions that exist around their environment.

According to the researchers' assumptions, an increase in attitude in the intervention group occurred because there was given information, knowledge and direct experience to students so that the results showed differences before and after the treatment of basic life support training and in the 
control group there were changes that were not too significant or only slightly increased because they were not given treatment of basic life support training.

Bivariat Analysis

1) The difference in the average demeanour of class XI students before and after being treated in each group using paired t-test

a. Control group

The results of normality tests conducted using Shapiro-Wilk produce data with normal distribution with p-values at the pre-test 0.916 and post-test $0.659(>0.05)$. In the control group the paired t-test results obtained a p-value of 0.000 , which states that there is a difference between before and after treatment is given to the control group. This can be seen from the mean before treatment 83.21 and the mean after treatment 84.55 . In this study there was an increase in attitude in the control group that was not too high, with a mean of 1.34 although no basic life support training was provided.

This is different from the 2012 Astriyana study which states based on the results of the paired sample t-test, showing that the control group had no effect without being given balance training to reduce the risk of falling because the p-value was $0.07>0.05$. This can happen considering the type of research conducted is quasy experimental which is a quasiexperimental, allowing many things that affect students' demeanour that cannot be controlled by researchers such as the mass media, the internet and the influence of others that are considered important etc..

\section{b. Intervention Group}

In the intervention group the results of the normality test conducted using Shapiro-Wilk produced data with normal distribution with $\mathrm{p}$-values at pre-test 0.476 and post-test 0.555 (> 0.05). The results of paired t-test in this study showed a difference between before and after being given treatment in the intervention group with p-value $=0.000$, the mean before being given 88.59 treatment and the mean after being given treatment was 95.62 which stated that there was an influence which is significant from basic life support training (BHD) towards the attitude of class XI students, this reinforces that basic life support training (BHD) can improve the attitude of class XI students and in accordance with Mathis and Jackson's theory (2011) training is a process where people get the capacity to help to carry out activities.

The results of this study reinforce the research conducted by Wisnu (2010) on the Effects of Health Education with Simulation Methods on Knowledge and Demeanour About First Aid in Accidents at SMK 1 Mojosongo, Boyolali. This study concluded that ( $\mathrm{p}$-value $=0,000$ ) with an average value of attitude pre-test was 48.55 and post-test of 56.94, so it was concluded that health education was effective in increasing demeanour about predisposing factors for respondents in SMK Negeri 1 Mojosongo Boyolali

So that researchers assume that training is the provision of information, knowledge, experience in which knowledge and experience are factors in the formation of motivation and demeanour, so that basic life support training (BHD) can affect respondents' motivation and demeanour.

1) The difference in the average demeanour of class XI students in the control group and the treatment group using the independent t-test.

Before calculating the results of the Independent t-test analysis in the treatment group and the control group first, the researchers conducted a normality test with the results of the sig value. in the pre-test 0.916 and post-test 0.659 (> 0.05) for the control group and the sig value. in the pre-test 0.476 and post-test $0.555(>0.05)$ for the treatment group so that it can be concluded that the data are normally distributed, then the independent t-test analysis test can be used.

Motivation and Attitude of students before the treatment of basic life support training obtained independent t-test results with a p-value of 0,000 , the mean in the control group was 83.21 with SD 6.217, while in the treatment group was 88.59 with SD 5.748 and Attitude students after the treatment of basic life support training obtained independent t-test results with a p-value of 0,000 , the mean for the control group 84.55 with SD 5.985 and the mean 95.62 in the treatment group with SD 3.816. 
Whereas the mean difference after being given basic life support (BHD) training between the control group and the treatment group was -11.06 with a $t$ value of -9.64 . Data from the above statistical test results with a p-value of 0,000 using the independent t-test can be concluded that $\mathrm{H} 0$ is rejected and $\mathrm{Ha}$ is accepted so that it can be said there is a statistical influence between basic life support training on motivation and demeanour of class XI students in state high schools 2 Tenggarong.

Based on the results of the research and explanation above, the researcher concludes that basic life support training is very beneficial for everyone, especially students (adolescents) because it can save lives and improve the quality of one's life so that basic life support training is very well taught from an early age (youth) because of information and insights that are planted early on are very important to be a human who cares for others.

So that our willingness and attitude to help others can be realized. Researchers assume that a person's attitude in providing support is the first step in a motivation in providing support to someone, if the attitude in providing support is not good then certainly motivation in providing support to someone is also low.

This is also consistent with Rizal's (2015) study that the reinforcement factor is every action taken and gets a good response, increasing the likelihood that the action will be repeated. Simply stated that this theory has a view that says that if a manager's actions by subordinates are seen as encouraging positive behavior, the subordinates concerned will tend to repeat similar actions.

\section{CONCLUSION}

The number of men in the intervention group was 17 people (44\%) and 19 people (49\%) in the control group. In the female sex group, the majority of respondents in the intervention group numbered 22 people $(56 \%)$ and for the control group they totaled 20 people $(51 \%)$. The age of respondents with the highest number was 16 years (56\%), the lowest number was 18 and 19 years old (3\%). In general respondents in the two groups had never received information about basic life support. As many as 31 people (79\%) had never received information about basic living assistance and the remaining 8 people $(21 \%)$ received information about basic living assistance from PMI in the intervention group. Similarly, the control group of 37 people (95\%) had never received information about basic living assistance and the remaining 2 people (5\%) received information about basic living assistance from the Puskesmas.

Based on the results of the study revealed that there were differences in attitude between before and after basic life support training was given to the control group with a p-value of 0,000 .

Based on the results of the study revealed that there are differences in motivation and demeanour between before and after basic life support training was given to the intervention group with a $p$-value of 0,000 .

Based on the results of research using the Independent t-test student demeanour before the treatment of basic life support training results obtained independent test results t-test with a p-value of 0,000 , the mean in the control group was 83.21 with SD 6.217, whereas in the group the treatment was 88.59 with elementary 5,748 and the attitude of the students after the treatment of basic life support training obtained independent t-test results with a p-value of 0,000 , the mean for the control group was 84.55 with an elementary 5.985 and the mean of 95.62 in the treatment group with SD 3,816. Whereas the mean difference after being given basic life support (BHD) training between the control group and the treatment group was -11.06 with a $t$ value of -9.64 . Data from the above statistical test results can be concluded that $\mathrm{HO}$ is rejected and $\mathrm{Ha}$ is accepted so that it can be said there is a statistical influence between basic life support training on the attitude of class XI students at SMA Negeri 2 Tenggarong.

BIBLIOGRAPHY

American Heart Association (AHA). (2010). Adult Basic Life Support:Guidelines For Cardiopulmonari Resuscitation and Emergency Cardiovascular Care, http://circ.ahajournals.org/content/122/18_suppl_3/S685, (di akses 21 Oktober 2017).

Hardisman. (2014). Gawat Darurat Medis Praktik. Yogyakarta: Gosyen Publishing.

Hutapea, Elda Lunera. (2012). Gambaran Tingkat Pengetahuan Polisi Lalu Lintas Tentang Bantuan Hidup Dasar (BHD) di Kota Depok, diperoleh tanggal 12 Juli 2018. 
Pamaya. 2014.Emilia Lumangkun,Lucky T.Kumaat dan Sefti Rompas. (2014). Hubungan Karakteristik Polisi Lalu IIntas dengan Tingkat Pengetahuan Bantuan Hidup Dasar. E-Jurnal Keperawatan, 2, (2)

Rizal, A. A. F. (2015). Hubungan Pelaksanaan Fungsi Manajemen Kepala Ruang Dengan Motivasi Perawat Pelaksana Dalam Memberikan Layanan Keperawatan Di Ruang Rawat Inap RSUD Kota Semarang. (Tesis diperoleh pada 11 Juli 2018).

Sitorus. (2011). Manajemen Keperawatan diruang Rawat. Jakarta : Sagung Seto.

Thoyyibah, D. ZA. (2014). Pengaruh Pelatihan Bantuan Hidup Dasar Pada Remaja Terhadap Tingkat Motivasi Menolong Korban Henti Jantung, http://Thesis.umy.ac.id/datapublik/t34049.pdf/, (diakses tanggal 21 Oktober 2017).

Wahyu Wulan Fitriyah, Muhammad Mashuri \& Irhamah.(2012). Faktor-faktor yang mempengaruhi keparahan korban kecelakaan lalu

Wawan, A. dan Dewi M. (2010). Teori dan Pengukuran: Pengetahuan, Sikap dan Perilaku Manusia. Yogyakarta: Nusa Medika

Wisnu Wijiyanto Putro.(2017). Pengaruh Pendidikan Kesehatan dengan Metode Simulasi Terhadap Pengetahuan dan Sikap Tentang Pertolongan Pertama pada Kecelakaan di SMKN 1 Mojosongo Boyolali. Skripsi, tidak dipublikasikan, Surakarta, Universitas Muhammadiyah Surakarta, Indonesia

World Health Organization. (2011). Kecelakaan Lalu Lintas. Wikipedian Ensiklopedia. Di Akses melalui http://id.wikipedia.org/wiki/hujan, (diperoleh 22 Oktober 2017). 